\title{
PERAN DAYA SAING KULTURAL DAN KAPABILITAS DINAMIK DALAM MENINGKATKAN KINERJA ORGANISASIONAL
}

\author{
Agustinus Dedy Handrimurtjahjo; Engkos Achmad Kuncoro \\ Management Department, School of Business and Management, Universitas Bina Nusantara \\ Jln. K.H. Syahdan No. 9, Palmerah, Jakarta Barat 11480 \\ ahandrimurtjahjo@binus.edu; eak@binus.edu
}

\begin{abstract}
This paper develops a conceptual framework for intended study which will examine the effect cultural competitiveness on dynamic capabilities and organizational performance. Previous study argued that four variables of Cultural Competitiveness (entrepreneurship, innovativeness, market orientation and organizational learning) have a direct effect on organizational performance. Meanwhile, the other study argued that dimensions of entrepreneurial orientation have a significantly positive effect on dynamic capabilities to different extents, while organizational learning, which has significantly positive effect on dynamic capabilities, plays a partial mediating role between the two. These findings indicate that companies can build dynamic capabilities through different levels of organizational learning in the context of innovative and proactive atmosphere.
\end{abstract}

Keywords: cultural competitiveness, dynamic capability, organizational performance

\begin{abstract}
ABSTRAK
Makalah ini mengembangkan sebuah kerangka kerja konseptual untuk studi yang dimaksudkan yang akan memeriksa efek persaingan budaya pada kemampuan dinamis dan kinerja organisasi. Penelitian sebelumnya berpendapat bahwa empat variabel Daya Saing Budaya (kewirausahaan, inovasi, orientasi pasar, dan pembelajaran organisasional) memiliki efek langsung pada kinerja organisasi. Sementara itu, studi lain berpendapat bahwa dimensi orientasi kewirausahaan berpengaruh signifikan positif pada kemampuan dinamis untuk luasan yang berbeda, sedangkan pembelajaran organisasi, yang memiliki efek positif dan signifikan pada kemampuan dinamis, memainkan peran mediasi parsial antara keduanya. Temuan ini menunjukkan bahwa perusahaan dapat membangun kemampuan dinamis melalui berbagai tingkat pembelajaran organisasi dalam konteks suasana inovatif dan proaktif.
\end{abstract}

Kata kunci: persaingan budaya, kemampuan dinamis, kinerja organisasi 


\section{PENDAHULUAN}

Cara yang paling jitu untuk memenangkan persaingan global masih belum nampak bagi beberapa perusahaan (Hamel dan Prahalad, 1990). Selama tahun 1980-an, eksekutif puncak dinilai dengan kemampuan mereka untuk melakukan restrukturisasi, rekayasa ulang dan memangkas struktur organisasi mereka. Tahun 1990-an, para eksekutif dinilai dengan kemampuan mereka untuk mengidentifikasi, mengembangkan, dan menggunakan core competencies yang membuat pertumbuhan-sehingga mereka harus memikirkan kembali konsep corporation. Bagaimanapun, dalam lingkungan bisnis yang bergerak cepat dan terbuka bagi persaingan global dan ditandai dengan penyebaran sumber-sumber inovasi dan manufaktur secara geografis dan organisasional, sustainable advantage memerlukan lebih dari sekedar kepemilikan aset (knowledge) yang sulit untuk direplikasi (difficult-to-replicate), tetapi juga memerlukan dynamic capabilities yang unik dan sulit untuk direplikasi (Teece, 2008).

Pendekatan dynamic capabilities mengkaji cara perusahaan membangun dan mempertahankan posisi bersaing mereka dalam situasi perubahan yang cepat dan tidak dapat diprediksi. Teece et al. (1997) mencatat bahwa pemenang di pasar adalah perusahaan-perusahaan yang dapat menjamin inovasi produk yang responsif dan cepat dengan mengadopsi dynamic capabilities. Mereka merumuskan dynamic capability sebagai "kemampuan perusahaan mengintegrasikan, membangun dan menata-ulang kompetensi internal dan eksternal untuk lingkungan yang berubah cepat”. Teori dynamic capability dibangun berdasarkan asumsi dasar resource-based view dan menggambarkan kemampuan organisasi untuk mencapai bentuk keunggulan kompetitif yang baru dan inovatifberdasarkan ketergantungan lintasan (path dependencies) dan posisi pasar (Leonard Barton, 1992 dalam Teece et al, 1997). Riset tentang teori dynamic capability saat ini memfokuskan pada konotasi dan definisi, komponen, konstruksi insentif dan faktor berpengaruh, yang menjelaskan mekanisme operatif dalam dynamic capability (Zollo dan Winter, 2002). Meskipun demikian, Zahra et al (2006) mengkritisi bahwa studi dalam teori dynamic capability saat ini kurang adanya uji empiris, mengabaikan entrepreneurship dan budaya organisasi yang berdampak pada dynamic capabilities. Sementara itu, teori entrepreneurship memainkan peran penting dalam bidang ini (Lumpkin dan Dess, 1996; Jantunen et al, 2005; Rothaermel dan Hess, 2007; Guido and Pierluigi, 2008;McKague, 2011).

Dynamic capability merupakan kemampuan entreprenuerial untuk menyesuaikan perubahan lingkungan yang cepat (Teece, 2008). Teece (2008) juga menyatakan bahwa komponendynamic capability yang terlibat dalam pembentukan (bukan sekedar menyesuaikan) lingkungan adalah karakteristik entrepreneurial. Perusahaan dengan dynamic capabilities yang kuat adalah sangat entrepreneurial. Mereka bukan hanya menyesuaikan ekosistem bisnis, tetapi juga membentuknya melalui inovasi dan kolaborasi dengan perusahaan dan institusi lainnya. Dari waktu ke waktu, organisasi mengembangkan orientasi terhadap entrepreneurship yang melekat dalam budayanya. Beberapa organisasi memilik entrepreneurship lebih dari yang lain, dan hal ini mempengaruhi orientasi mereka terhadap faktor daya saing seperti innovativeness, customer dan market dan learning (Hult et al, 2003). Selanjutnya, Hult et al (2003) menyatakan bahwa empat faktor berbasis budaya tersebut - entrepreneurship, innovativeness, market orientation dan organizational learning secara bersama-sama meningkatkan daya saing kultural organisasi (cultural competitiveness) yaitu tingkat dimana organisasi cenderung mendeteksi dan memenuhi kesenjangan antara apa yang diinginkan oleh market dan apa yang ditawarkan oleh market saat ini. Sehingga perlu dikembangkan suatu kerangka konsep hubungan antara dynamic capabilities dan cultural competitiveness.

Paper ini bertujuan untuk menunjukkan peran dynamic capabilities dan cultural competitiveness dalam meningkatkan kinerja organisasional. Secara khusus, paper ini juga bertujuan untuk mengkaji bagaimana mengembangkan dynamic capabilities melalui pemanfaatan entrepreneurship, innovativeness, market orientation dan organizational learning. 


\section{METODE}

Untuk membahas topik yang dikaji dalam tulisan ini digunakan Metode Kajian Pustaka (Literature Review). Kajian Pustaka ini dimaksudkan untuk memecahkan suatu masalah yang pada dasarnya bertumpu pada penelaahan kritis dan mendalam terhadap bahan-bahan pustaka yang relevan. Telaah pustaka dilakukan dengan cara mengumpulkan data atau informasi dari berbagai sumber pustaka yang diperlukan sebagai sumber ide untuk menggali pemikiran atau gagasan baru, sebagai bahan dasar untuk melakukan deduksi dari pengetahuan yang sudah ada, sehingga kerangka teori baru dapat dikembangkan, atau sebagai dasar pemecahan masalah. Pendekatan literature review, terdiri dari 5 tahap yaitu terdiri dari: 1) Find models, 2) Problem formulation - which topic is under consideration and what are the constituent issues, 3) Literature search, 4) Evaluation of findings, dan 5) Analysis and interpretation of literature.

Sumber-sumber pustaka yang dikaji dalam tulisan ini berupa: buku, hasil penelitian, jurnal, dan artikel ilmiah lainnya. Langkah-langkah pembuatan literature review dijabarkan sebagai berikut. Pertama, menetapkan sumber-sumber untuk bahan literature review yang sesuai dengan topik kajian tulisan ini. Kedua, mengevaluasi isi yang dimuat di dalam sumber-sumber studi pustaka yang ditetapkan. Pada bagian ini dapat dimuat hal-hal yang berkaitan dengan anggapan-anggapan dasar atau fakta-fakta yang dipandang benar tanpa adanya verifikasi dan keterbatasan, yaitu aspek-aspek tertentu yang dijadikan kerangka berpikir. Analisis ini diperlukan untuk menyusun alur berpikir dalam memecahkan masalah. Ketiga, membuat summary terhadap isi sumber-sumber studi pustaka. Dan keempat, menggali pemikiran dan gagasan baru terhadap topik yang menjadi bahan kajian untuk menetapkan positioning konsep sebagai bahan penelitian berikutnya.

\section{Kerangka Teoritis}

\section{Entrepreneurship}

Entrepreneurship seperti yang diungkapkan oleh Schumpeter merupakan hal yang penting dalam pembangunan ekonomi (Hult et al 2003). Schumpeter membuat perbedaan antara entrepreneurship sebagai fungsi dan entrepreneur sebagai orang. Seorang entrepreneur dapat menjadi seseorang yang menciptakan inovasi - pengusaha mandiri, seorang karyawan atau manajer perusahaan dll. Lebih lanjut, serangkaian inovasi diciptakan oleh entrepreneur tak terbatas secara virtual, meliputi pengembangan produk/jasa baru, saluran distribusi baru atau reorganisasi industri keseluruhan (Birkinshaw, 2000 dalam Hult et al 2003). Entrepreneurship sebagai fungsi merujuk pada gangguan keseimbangan dalam perusahaan (atau ekonomi) yang disebabkan oleh penciptaan dan aplikasi kombinasi baru sumber daya. Tingkatan entrepreneurship juga bervariasi dalam lintas organisasi. Sebagai contoh, perusahaan yang mengejar strategi "prospector", rata-rata lebih mengkombinasikan sumberdaya dibandingkan perusahaan yang mengejar strategi "defender" (Miles \& Snow, 1978). Dari waktu ke waktu, organisasi mengembangkan orientasi terhadap entrepreneurship yang menyatu dengan budayanya. Beberapa organisasi menaruh perhatian entrepreneurship lebih dari yang lain, dan hal ini mempengaruhi orientasi mereka terhadap faktor daya saing lainnya seperti innovativeness, customers dan markets, dan learning.

\section{Innovativeness}

Karena innovativeness memainkan peran penting dalam kesuksesan perusahaan dalam memperoleh keunggulan bersaing yang berkelanjutan, berbagai studi mencoba mengungkapkan hubungan antara innovativeness dan kinerja (Lin, Peng and Kao 2008). Organisasi yang beroperasi dalam lingkungan dinamis mungkin lebih bermanfaat dalam inovasi produk baru dibandingkan perusahaan yang beroperasi dalam lingkungan yang stabil (Miller, 1983; Miller, 1988; Zahra, 1993 
dalam Kreiser and Davis 2010). Drucker (1985) dalam Lee \& Shieh (2010) mempertimbangkan inovasi karena memberikan sumberdaya kemampuan baru untuk menciptakan kemakmuran. Inovasi, penemuan atau adopsi sesuatu yang baru atau berbeda, secara konsep sangat dekat dengan entrepreneurship atau penciptaan kombinasi baru sumberdaya (Hult et al 2003).

Innovativeness menyiratkan perusahaan menjadi proaktif dengan menggali peluang baru bukan sekedar hanya memanfaatkan kekuatan saat ini (Menguc and Auh 2006). Oleh karenanya, perbedaan berikutnya dibuat oleh Zaltman, Duncan and Holbeck 1973 in Hult et al. 2003, memfokuskan studi pada "innovativeness" yang merupakan orientasi kultural organisasi (nilai dan keyakinan) terhadap inovasi. Innovativeness dapat dibedakan dari kapasitas berinovasi, yang merupakan kemampuan organisasi untuk berkembang secara sukses atau mengadopsi produk dan proses baru (Cohen \& Levinthal, 1990 dalam Hult et al. 2003). Innovativeness, jika dikombinasikan dengan faktor daya saing kultural dapat menciptakan kapasitas yang lebih besar untuk berinovasi yang sebaliknya mengakibatkan kinerja organisasional unggul (Hult et al. 2003). Untuk menjadi lebih spesifik, perusahaan yang berorientasi pada perubahan nilai inovasi dan mendorong pengambilan resiko dan kreativitas, membuat karyawan merasa kurang terancam ketika mempertaruhkan upaya ke dalam bidang baru (Zhang and Duan, 2010). Deshpande et al (1993) dalam Hult (2001) juga menemukan bahwa innovativeness yang diwujudkan dalam budaya perusahaan memiliki dampak positif pada kinerja bisnis.

\section{Market Orientation}

Orientasi pada merupakan prinsip dasar kultural organisasi belajar (Slater and Narver 1995 dalam Hult et al. 2003). Salah satu dasar rumusan RBV adalah bahwa perusahaan bernilai, jarang, rumit secara sosial dan sumberdaya yang sulit ditiru menghasilkan keunggulan bersaing dan dengan demikian tingkat pengembalian diatas normal (Barney 1991; Wernerfelt 1984 dalam Menguc and Auh 2006). Organisasi yang digerakkan pasar merupakan organisasi yang menempatkan prioritas tinggi dalam menciptakan nilai bagi konsumen yang ada dan potensial (Day, 1994 dalam Hult et al. 2003). Perusahaan dengan budaya berorientasi pasar mengembangkan kapabilitas dalam intelijen pasar dan strategi mereka responsif terhadap informasi yang dikumpulkan dari konsumen dan pihak berkepentingan eksternal lainnya. Perusahaan itu juga mengembangkan kemampuan untuk mengkoordinasikan proses internal sehingga mereka dapat bertindak dengan cepat dan efektif (Day, 1994; Narver \& Slater, 1990 dalam Hult et al. (2003). Orientasi pasar yang kuat, jika bergabung dengan budaya yang menekankan entrepreneurship dan innovativeness memunculkan organizational learning (Slater \& Narver, 1995 dalam Hult et al. 2003). Orientasi pasar juga telah dihubungan dengan keinovatifan. Seperti disarankan oleh Drucker (1954) dalam Ollavarieta and Friedmann (1999), marketing dan inovasi adalah dua fungsi yang saling berhubungan untuk setiap bisnis.

Meskipun beberapa kerangka orientasi pasar yang layak ada (Deshpandé, Farley \& Webster, 1993; Kohli \& Jaworski, 1990 dalam Hult et al. 2003), kita mengadopsi konseptualisasi Narver and Slater (1990) karena fokus pada budaya organisasi. Dari arti penting tertentu dalam kerangka mereka berpengaruh pada orientasi konsumen, pesaing dan koordinasi antar fungsi. Dimensi orientasi pasar oleh karenanya menjadi bagian dari daya saing kultural organisasi (Hult et al. 2003). Slater dan Narver dalam Hult et al (2002) menyarankan bahwa orientasi pasar merupakan hal yang tak terpisahkan dengan organisasi belajar.

\section{Organizational Learning}

Pembelajaran organisasional dirumuskan sebagai proses pengunaan pengetahuan dan wawasan dengan tujuan untuk meningkatkan perilaku dan kinerja (Fiol and Lyles, 1985; Huber, 1991; Simon, 1991 dalam Tran 2008). Pengetahuan, diturunkan dari pembelajaran, secara potensial merupakan sumber daya yang paling produktif dalam organisasi dan dapat menjadi sumber daya keunggulan bersaing (Barney, 1991; Grant, 1996 dalam Hult et al. 2003). Persediaan pengetahuan 
organisasi diciptakan dan diperluas melalui proses pembelajaran (Daft \& Huber, 1987; Daft \& Weick, 1984 dalam Hult et al. 2003). Proses pembelajaran yang efektif dalam organisasi melibatkan beberapa tahap utama, setiap tahap harus dirancang dan dikelola secara hati-hati: pemerolehan informasi, interpretasi, eksperimen yang terfokus, penyebaran pengalaman dan restrukturisasi pengetahuan (Hanssen-Bauer \& Snow, 1996 dalam Hult et al. 2003).

Pembelajaran organisasional digambarkan sebagai pembelajaran di tempat kerja, yang merupakan gaya pembelajaran tingkat rendah melibatkan penggunaan pengetahuan yang ada untuk meningkatkan efisiensi operasi dalam perusahaan berskala kecil (Badger et al., 2001; Chaston et al., 2001 dalam Keskin 2006). Pembelajaran organisasional merupakan kapabilitas yang memungkinkan perusahaan menciptakan pengetahuan sebagai sumber kinerja yang meningkat (Hitt \& Ireland, 2000 dalam Dess et al. 2003). Fokus studi pada nilai dan keyakinan bersamaan dengan pembelajaran organisasional. Dalam hal ini, perhatian kita pada bagaimana manajer memandang aspek tertentu dalam proses pembelajaran seperti nilai timkerja lintas fungsi, antar-keterhubungan berbagai bagian dalam organisasi dan apakah ada mekanisme untuk berbagi pengetahuan dan pengalaman (Hult et al. 2003). Pembelajaran organisasional bernilai bagi konsumen perusahaan karena memfokuskan pada pemahaman dan secara efektif memuaskan ungkapan mereka dan kebutuhan yang tersembunyi melalui produk, layanan dan cara-cara baru dalam melakukan bisnis (Slater and Narver, 1995; Lukas et al, 1996 dalam Lopez et al. 2005).

\section{Dynamic Capabilities}

Dynamic capabilities mengacu pada kapabilitas perusahaan untuk memadukan, mengembangkan dan menata-ulang kompetensi internal dan eksternal pada lingkungan yang berubah dengan cepat (Teece et al, 1997).Untuk mengartikan seberapa efektif dynamic capabilities mempengaruhi keunggulan bersaing, beberapa peneliti telah mengkaji mekanisme operasional. Sebagai contoh, dynamic capabilities dapat pengetahuan teknis berkaitan dengan dasar pengetahuan yang ada selama evolusi model operasi bisnis dan teknis mereka yang secara dinamis meningkatkan aktivitas yang ada (Zollo andWinter, 2002; Helfat and Peteraf, 2003; Winter, 2003). Peneliti ini menunjukkan fitur yang diperbaharui dan fleksibel tentang inovasi dan mengurangi pengulangan dalam definisi dynamic capabilities. Seperti disebutkan diatas, dynamic capabilities terdiri atas empat komponen: (1) environmental sensing capabilities (Prahalad and Hamel, 1990; Lawson and Samson, 2001; Li, 2006 dalam Jiao et al., 2010); (2) change and renewal capabilities(Teece et al., 1997; Zollo dan Winter, 2002; Helfat dan Peteraf, 2003); (3) technological flexibility capabilities (Ianisti danClark, 1994; Collis, 1994 dalam Jiao et al., 2010); dan (4) organizational flexibility capabilities (Chandler, 1962; Nelson dan Winter, 1982; Zollo dan Winter, 1999 dalam Jiao et al., 2010). Berturut-turut, kapabilitas ini menunjukkan kemampuan merespon secara sensitif dan mengidentifikasi perubahan dalam industri, kompetensi untuk berinovasi dan mengubah dan fleksibilitas dalam teknologi dan struktur organisasi.

\section{Environmental Sensing Capabilities}

Top managers dan ahli teknik memahami peluang pengembangan pasar secara mendalam. Hal ini dinyatakan oleh Prahalad and Hamel (1990); mereka menekankan bahwa perusahaan seharusnya memperdalam pemahaman mereka tentang hukum dalam industri dan meraih pada perubahan tren. Lawson and Samson (2001) dalam Jiao et al.(2010) juga percaya bahwa sistem intelijen merupakan satu elemen dynamic capabilities. Li (2006) dalam Jiao et al., (2010) menemukan bahwa semua kegiatan yang dilakukan oleh perusahaan menyesuaikan perubahan lingkungan pertama berasal dari kapabilitas secukupnya penginderaan lingkungan. Bagian kritis kapabilitas berwawasan lingkungan terletak dalam pengenalan konsekuensi yang disebabkan oleh perubahan lingkungan. 


\section{Change and renewal capabilities}

Collis (1994) dalam Jiao et al., (2010) menyatakan bahwa kapabilitas untuk memadukan sumber daya sangat berharga. Teece et al. (1997) menunjukkan bahwa dynamic capabilities bukan hanya sekadar mampu untuk mengembangkan, menata-ulang dan memadukan sumberdaya, tetapi juga memadukan, melakukan inovasi dan memperbaharui proses operasional. Zollo and Winter (2002), dan Helfat and Peteraf (2003) juga menunjukkan bahwa dynamic capabilities adalah memperbaiki operasi, sehingga bisa menyesuaikan terhadap perubahan lingkungan.

\section{Technological flexibility capabilities}

Berdasarkan pendapat dari Ianisti and Clark (1994) dalam Jiao et al., (2010), merupakan hal yang penting bahwa teknologi saat ini seharusnya meningkat secara cepat untuk memenuhi kebutuhan konsumen yang didasarkan pada produk atau jasa tertentu. Perusahaan seharusnya mampu memilih dari pengetahuan teknis berkaitan dengan dasar-dasar pengetahuan yang ada saat ini selama tahap evolusi yang relevan dengan tujuan untuk melaksanakan jenis asosiasi ini. Kemampuan untuk bersaing pada tingkat teknologi didasarkan pada kapabilitas dalam versi sebelumnya teknologi tersebut. Collis (1994) dalam Jiao et al., (2010) lebih lanjut menyatakan bahwa teknologi saat ini seharusnya menyenangkan secara fungsi untuk peningkatan lini dan layanan produk baru.

\section{Organizational flexibility capabilities}

Organizational flexibility capabilitiesmengacu pada atribut struktur organisasi yang peduli pada otoritas pembuatan keputusan, tugas konfigurasi dan arus informasi. Chandler (1962) dalam Jiao et al., (2010) menyatakan bahwa struktur organisasi seharusnya mengikuti strategi. Dalam hal ini, pelaksanaan strategi memerlukan bahwa perusahaan mengijinkan departemen yang berbeda dipecah melalui prosedur formal sehingga mempertahankan fleksibilitas dan dinamika pekerjaan. Oleh karena itu, perusahaan yang menudkung fleksibilitas organanisasi selalu lebih cepat dibandingkan pesaing. Zollo and Winter (1999) dalam Jiao et al., (2010) menyatakan bahwa struktur organisasi seharusnya fleksibel, sehingga tidak membantu rutinitas organisasi. Perusahaan harus berorientasi pada konsumen pada berbagai saat tertentu, berjuang untuk membidik yang memperkembangkan nilai dan memuaskan permintaan konsumen dan mendasarkan pada kapabilitas penginderaan lingkungan dan kapabilitas menanggapi dengan cepat sehingga mereka secara dinamis menyesuaikan perubahan lingkungan eksternal yang rumit. Akhirnya, perusahaan dapat mewujudkan kesesuaian terbaik antara sumberdaya dan lingkungan dinamis. Dengan melakukan inovasi dan pembaharuan dinamis, perusahaan memperoleh informasi dari perubahan lingkungan, manata-ulang dan memadukan sumberdaya melalui kapabilitas fleksibel teknologi dan organisasional dan dengan demikian mencapai daya saing yang langgeng (Jiao et al., 2010).

\section{Organizational Performance}

Beberapa studi pada perusahaan skala besar, telah mencatat interaksi atribut lingkungkan industri dengan strategi, kompetensi yang berbeda dan struktur perusahan yang berpengaruh pada kinerja (Hambrick, 1983a; Hitt dan Ireland, 1985 dalam Pelham, 1999). Ada karakteristik multidimensi terhadap kinerja organisasi (Pelham, 1999). Sebagai contoh: marketing/sales effectiveness(relative product quality, new product success and customer retention), growth/share(level of sales revenue, sales growth and target market share) dan profitability (return on equity, return on investment and gross profit margin). Dalam paper ini pengukuran kinerja organisasional akan menggunakan growth dan profitability. 


\section{HASIL DAN PEMBAHASAN}

Langkah utama dalam membangun kerangka konsep yang berhubungan dengan dynamic capabilities adalah mengidentifikasi dasar-dasar keunggulan yang berbeda dan sulit untuk direplikasi, bisa dibangun, dipertahankan dan ditingkatkan (Teece at al, 1997). Teori pertumbuhan perusahaan menekankan pentingnya sumberdaya internal dan pembelajaran intra-organisasional sesuai dengan lingkungan eksternal(Penrose 2009). Persaingan antara perusahaan menjadi lebih bergejolak, yang mendorong perusahaan untuk melatih dan meningkatkan kapabilitas dalam integrasi, pembangunan dan penataan-ulang sumber daya internal dan eksternal untuk mengatasi perubahan lingkungan (Teece et al, 1997). Melalui cara ini, kapabilitas mengubah mekanisme operasional yang ada dengan tujuan untuk memuaskan pelanggan dan pasar baru dan akhirnya meningkatkan kinerja (Jiao et al, 2010). Teece et al, 1997 membahas konotasi dan hubungan antara organizational learning dan dynamic capabilities dari perspektif proses, rutin dan knowledge management.

Beberapa perusahaan mencoba menggunakan entrepreneurial orientation untuk mengembangkan dynamic capabilities. Sebagai contoh, Jantunen et al. (2005) menggunakan data survei dalam sektor manufaktur dan jasa dan mengkaji hubungan antara entreprenuerial orientation, reconfiguring capabilities dan kinerja. Hasil empiris menunjukkan bahwa entreprenuerial orientation dan reconfiguring capabilites memiliki hubungan positif terhadap kinerja international. Hasil studi empiris yang dilakukan Jiao et al (2010) pada 108 perusahaan manufaktur dan jasa di China, menyatakan bahwa dimensi entrepreneurial orientation memiliki dampak positif yang signifikan pada dynamic capabilities untuk tujuan yang berbeda, sementara organizational learning yang memiliki dampak positif secara signifikan terhadap dynamic capabilities memainkan peran mediasi parsial antara keduanya.

Hasil studi yang dilakukan Hult et al (2003) pada 764 Unit Bisnis Strategis (SBU) di perusahaan manufaktur menyatakan bahwa diantara empat variabel (entrepreneurship, innovativeness, market orientation dan organizational learning), entrepreneurship menunjukkan variabel yang paling berpengaruh dan cara yang proaktif dalam pengembangan budaya berbasis pasar (market-based culture). Dari hasil studi diatas, dapat dikembangkan kerangka konsep tentang peran Daya Saing Kultural dan Kapabilitas Dinamis dalam meningkatkan Kinerja Organisasional seperti yang terdapat dalam Gambar 1.

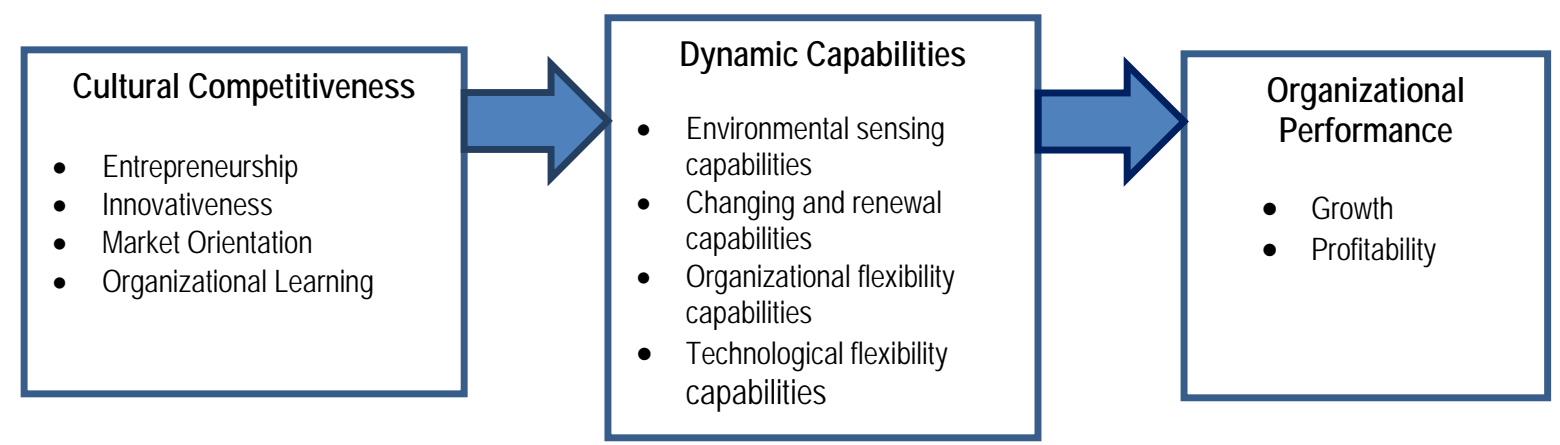

Gambar 1 Model Konseptual Daya Saing Kultural dan Kapabilitas Dinamis 


\section{PENUTUP}

Paper ini membahas tentang pengembangan kerangka konsep untuk menujukkan peran daya saing kultural dan kapabilitas dinamis dalam meningkatkan kinerja organisasional. Daya Saing Kultural diduga memiliki pengaruh terhadap pengembangan Kapabilitas Dinamis dan mampu meningkatkan Kinerja Organisasional. Paper ini perlu ditindaklanjuti dengan melakukan penelitian empirik dan menguji model yang diusulkan dengan tujuan untuk menemukan hasil yang diharapkan.

\section{DAFTAR PUSTAKA}

Calantone, R. J., Cavusgil, S. T. and Zhao, Y. (2002). Learning orientation, firm innovation capability and firm performance. Industrial Marketing Management, Vol.31, 515-524.

Dess, G. G., Ireland, R. D., Zahra, S. A., Floyd, S. W., Janney, J. J., and Lane, P. J. (2003). Emerging issues in corporate entrepreneurship. Journal of Management, Vol. 29 No. 3 pp. 351-378.

Eisenhardt K M, Martin M (2000). Dynamic capabilities: What are they? Strategic Management Journal, 21(10): 1105-1121.

Hult, G. T. M., and Hurley, R, F. (1998). Innovation, Market Orientation, and Organizational Learning: an Integration and Empirical Examination. Journal of Marketing, Vol. 62, 42-54.

Hult, G. T. M. (2001). Cultural Competitiveness in Global Sourcing. Industrial Marketing Management, Vol. 31, 25-34.

Hult, G. T. M., Ketchen JR, David.J., and Nicholis JR, Ernest. L. (2002). An Examination of Cultural Competitiveness and Order Fulfillment Cycle Time Within Supply Chains. Academy of Management Journal, Vol. 45. No. 3, 577-586.

Hult, G. T. M., Snow, C. C., and Kandemir, D. (2003). The Role of Entrepreneurship in Building Cultural Competitiveness in Different Organizational Types. Journal of Management, 29(3): 401-426.

Hao Jiao, Jiang Wei, Yu Cui (2010). An Empirical Study on Paths to Develop Dynamic Capabilities: From the Perspectives of Entrepreneurial Orientation and Organizational Learning. Management World, (4): 91-106.

Helfat C. E., Peteraf, M. A. (2003). The Dynamic Resource-Based View: Capability lifecycles. Strategic Management Journal, 24(10): 997-1010.

Keskin, H., (2006). Market Orientation, Learning Orientation and Innovation Capabilities In SMEs. European Journal of Innovation Management, Vol. 9 No. 4, pp. 396-417.

Knight, G. A. (1997). Cross-Cultural Reliability and Validity of a Scale to Measure Firm Entrepreneurial Orientation. Journal of Business Venturing, 12: 213-225.

Kreiser, P. M., and Davis, J. (2010). Entrepreneurial Orientation and Firm Performance: The Unique Impact of Innovativeness, Proactiveness, and Risk-taking. Journal of Small Business and Entrepreneurship, 23, no. 1: pp. 39-51. 
Jantunen, A., Puumalainen, K., Saarenketo, S., KylÃheiko, K. (2005). Entrepreneurial orientation, dynamic capabilities and international performance. Journal of International Entrepreneurship, 3: 223-243.

Lee, Jia-Sheng and Hsieh, Chia-Jung. (2010). A research in relating entrepreneurship, marketing capability, innovative capability and sustained competitive advantage. Journal of Business \& Economic Research, Vol. 8, No. 9 pp. 109-119.

Lin, Chien-Huang., Peng, Ching-Huai., and Kao, D. T. (2008). The innovativeness effect of market orientation and learning orientation on business performance. International Journal of Manpower, Vol. 29 No. 8, 2008 pp. 752-772.

Lopez, S. P., Peon, J. M. M., and Ordas, C. J. V. (2005). Organizational learning as a determining factors in business performance. The Learning Organization, Vol. 12, No. 3 pp. 227-245.

Menguc, B., and Auh, S., (2006). Creating a Firm-Level Dynamic Capability through Capitalizing on Market Orientation and Innovativeness. Academy of Marketing Science Journal, Vol. 34, No. 1, pp. 63-73.

Morgan, R.E., \& Strong, C. A. (2003). Business Performance and Dimensions of Strategic Orientation. Journal of Business Research, 56: 163-176.

Miles, R. E., \& Snow, C. C. 1978. Organizational strategy, structure, and process. New York: McGraw-Hill.

Narver, J. C., and Slater, S. F. (1995). Market Orientation and The Learning Organization. Journal of Marketing, Vol 59, 63-74.

Narver, J. C., and Slater, S. F. (1990). The Effect of a Market Orientation on Business Profitability. Journal of Marketing, 54: 20-35.

Olavarrieta, S., and Friedmann, R. (1999). Market-Oriented Culture, Knowledge-Related Resources, Reputational Assets and Superior Performance: A Conceptual Framework. Journal of Strategic Marketing, Vol. 7, 215-228.

Prahalad, C. K., Hamel, G. (1990). The core competencies of the corporation. Harvard Business Review, 66: 79-91.

Penrose, E. T. (2009). The Theory of Growth of the Firm. Oxford University Press Inc., New York. Fourth edition.

Pelham, A. M. (1999). Influence of Environment, Strategy, and Market Orientation on Performance in Small Manufacturing Firms. Journal of Business Research, 45: 33-46.

Tanriverdi, H., and Zehir, C. (2006). Impact of Learning Organization’ Application and Market Dynamism on Organizations' Innovativeness and Market Performance. The Business Review, Cambridge, Vol. 6, 2, 238-245.

Tran, T. (2008). A Conceptual Model of Learning Culture and Innovation Schema. Competitiveness Review: an International Business Journal, Vol. 18, No. 3 pp. 287-299.

Teece, D. J., Piano G., Shuen, A. (1997). Dynamic Capabilities and Strategic Management. Strategic Management Journal, 18(7): 509-533 
Teece, D. J. (2009). Dynamic Capabilities and Strategic Management. Oxford University Press. First edition.

Zahra, A. S., (2008). Being Entrepreneurial and Market Driven: Implications for Company Performance. Journal of Strategic and Management, Vol. I No. 2 pp. 125-142.

Zang, J., and Duan, Y. (2010). The Impact of Different Types of Market Orientation on Product Innovation Performance: Evidence from Chinese Manufacturers. Management Decision, Vol. 48, No. 6 pp. 849-867.

http://www.lboro.ac.uk/library/skills/ 